\begin{abstract}
Iranica
Abstracta Iranica Revue bibliographique pour le domaine irano-aryen

Volume 32-33 | 2013

Comptes rendus des publications de 2009-2010

\section{Christelle Jullien. La Chronique du Ḥūzistān. Une page d'histoire sassanide}

\title{
Rédaction
}

\section{(2) OpenEdition}

1 Journals

\section{Édition électronique}

URL : http://journals.openedition.org/abstractairanica/40527

DOI : 10.4000/abstractairanica.40527

ISSN : 1961-960X

Éditeur :

CNRS (UMR 7528 Mondes iraniens et indiens), Éditions de l'IFRI

\section{Édition imprimée}

Date de publication : 1 décembre 2013

ISSN : 0240-8910

\section{Référence électronique}

Rédaction, "Christelle Jullien. La Chronique du Hūzistān. Une page d'histoire sassanide », Abstracta Iranica [En ligne], Volume 32-33 | 2013, document 178, mis en ligne le 01 juillet 2016, consulté le 05 octobre 2020. URL : http://journals.openedition.org/abstractairanica/40527 ; DOI : https://doi.org/ 10.4000/abstractairanica.40527

Ce document a été généré automatiquement le 5 octobre 2020.

Tous droits réservés 


\section{Christelle Jullien. La Chronique du Hūzistān. Une page d'histoire sassanide}

\section{Rédaction}

\section{RÉFÉRENCE}

Christelle Jullien. « La Chronique du Ḥūzistān. Une page d'histoire sassanide », in : Ph. Gignoux, C. Jullien, F. Jullien, éds., Trésors d'Orient. Mélanges offerts à Rika Gyselen. Paris, 2009, p. 159-186. (Studia Iranica. Cahier 42).

Cet article propose une brève introduction et une traduction en français (la première à ce jour) d'un chronique syriaque relatant des événements choisis d'histoire religieuse et profane depuis l'époque d'Hormizd IV jusqu'à la fin de l'époque sassanide. Elle était publiée en latin dans le CSCO.

\section{AUTEURS}

\section{RÉDACTION}

Direction de la revue et secrétariat (Paris) 